\title{
Ecological Plasticity and Stability of Spring Bread Wheat Varieties by Yield Level in Agro-Ecological Zones of the Forest-Steppe and Polissia of Ukraine
}

\author{
Ruslan Blyzniuk*, Oleksandr Demydov, Svitlana Khomenko, Iryna Fedorenko, Denys Berezovskyi, \\ Maryna Fedorenko, Iryna Pravdziva, Liudmyla Ivantsova, Serhii Voloshchuk
}

Department of Cereal Crops Breeding, the V. M. Remeslo Myronivka Institute of Wheat of the National Academy of Agrarian Sciences of Ukraine, Tsentralne, Ukraine

\section{Email address:}

bliznyuk359@gmail.com (R. Blyzniuk)

${ }^{*}$ Corresponding author

\section{To cite this article:}

Ruslan Blyzniuk, Oleksandr Demydov, Svitlana Khomenko, Iryna Fedorenko, Denys Berezovskyi, Maryna Fedorenko, Iryna Pravdziva, Liudmyla Ivantsova, Serhii Voloshchuk. Ecological Plasticity and Stability of Spring Bread Wheat Varieties by Yield Level in AgroEcological Zones of the Forest-Steppe and Polissia of Ukraine. American Journal of Agriculture and Forestry. Vol. x, No. x, 2021, pp. x-x. doi: 10.11648/j.ajaf.20210902.13

Received: February 22, 2021; Accepted: March 11, 2021; Published: March 17, 2021

\begin{abstract}
The weather conditions in the two ecological zones Forest-Steppe and Polissia of Ukraine differed considerably in temperature regime and rainfed environments both during growing season as a whole and during particular phases of plant development. This made it possible to estimate spring bread wheat varieties by the levels of realizing their plant productivity potential. The productivity of spring wheat plants mainly depends on the growing zone (29.2\%), hydrothermal vegetation conditions $(16.3 \%)$, as well as their interaction (27.1\%). There have been identified the varieties of spring bread wheat Simkoda myronivs'ka, Struna myronivs'ka, MIP Zlata (UKR), Koksa (POL), Leguan (CZE) with increased yield level that were recommended to be grown in ecological zones Forest-Steppe and Polissia. The calculation of ecological plasticity and stability allowed differentiating the varieties of spring bread wheat in accordance with their responsiveness to variatione of growing conditions as well as with adaptive potential. High plasticity by yield level under growing conditions of the ForestSteppe and Polissia zones was determined in the varieties: Koksa $(P O L)\left(b_{i}=1.02\right)$, Simkoda myronivs'ka $(U K R)\left(b_{i}=1.02\right)$, Granny (AUT) $\left(b_{i}=1,03\right)$, Heroinia (UKR) $\left(b_{i}=1.01\right)$, Etiud (UKR) $\left(b_{i}=1.02\right)$. These varieties may be characterized by adaptive properties as intensive ones with a pronounced response to the environment, i.e. relatively high grain yields may be resulted from a specific response to more favorable growing conditions. There were identified the most stable varieties for terms of yield in two ecological zones Yasna (POL), Siuita, Panianka, Kharkivs'ka 26, Elehiia myronivs'ka (UKR).
\end{abstract}

Keywords: Yield, Spring Wheat Varieties, Ecological Plasticity and Stability, Agro-ecological Zone, Hydrothermal Conditions, ANOVA

\section{Introduction}

One of the most important breeding and ecological tasks is the realization of genetic potential of crop varieties in changing conditions due to their high ecological plasticity and wide response to changing factors that will provide stable grain yields with high technological quality [10, 18]. The solution of these problems is impossible without estimating stability of genetic parameters in different environmental conditions; in this regard, it is of great interest to study response of a set of spring bread wheat varieties by yield, ecological stability and plasticity to anthropic and environmental factors $[14,17]$.

The adaptability of varieties to environmental conditions is assessed on the basis of yield analysis over a number of contrasting years or testing them in different soil and climatic conditions [2]. According to A. A. Zhuchenko, the potential yield of varieties and hybrids is realized only by $25-40 \%$ due to insufficient plant resistance to abiotic and biotic stressors. 
Most modern varieties are not sufficiently adapted to the design of highly productive, environmentally sustainable agroecosystems and agrolandscapes [20].

Climate change taking place in recent decades in Ukraine requires qualitatively new approaches to the creation of new crop varieties including wheat. In the current breeding activity the level of adaptive potential of a new variety is number one in terms of its ability to adapt to various changes in meteorological factors [5, 9]. Development and implementation of breeding program based on the principles of adaptive selection makes it possible to create wheat germplasm which is characterized by high environmental plasticity and provides high yield performance in a wide range of weather conditions. In the future this will enable to create new wheat varieties of universal type. Such varieties minimally reduce productivity and protein content under stressful conditions, mainly due to insufficient soil moisture and high temperatures [7].

Ecological plasticity is understood as the ability of a variety to form high yields under different soil and climatic conditions in different years of cultivation. If we take the degree of response to changing conditions as the ecological plasticity of a variety, then the variety with high plasticity can easily increase its yield with improving conditions, and just as easily reduce it with deteriorating ones. Varieties with higher plasticity usually are suitable for growing in favorable conditions on high agricultural background. While the varieties with lower plasticity are less responsive to changes in the environment and are most suitable for growing under less favorable conditions, since they are able less reduce productivity $[3,19]$. Ecological stability characterizes regularity of the genotype responsiveness and the replicability of its modification variability. According to V. V. Khangil'din and N. A. Litvinenko, the best varieties with high and medium value of traits and the least variation of them in dependence to growing conditions are stable or homeostatic [4]. Altukhov Yu. $\mathrm{P}$. considers that a variety with an average, but stable yield is of greater economic value than a variety with a potentially high yield, but with a large variation in yield [1].

Adaptability of the variety is one of the most important properties, so this feature is given considerable attention in breeding programs in most countries. The concept of ecological stability which reflects the ability of a variety to withstand stressors is closely related to adaptability. The issue of stabilization of wheat grain harvest is acute, which stimulates the search for increasing adaptive potential in newly developed varieties [6].

Bread wheat as one of the main food crops is characterized by higher requirements to the most important environmental factors being particularly diverse, severe, and variable over time and space. Creation of varieties with high ecological plasticity and yield stability over the years is current problem of modern plant breeding [20]. It is especially spring wheat which is more susceptible to stress than winter wheat. In the conditions of the Forest-Steppe of Ukraine, more plastic winter wheat varieties, but more stable spring wheat varieties prevailed in terms of productivity. The regions of origin of wheat varieties with different types of response to changes in environmental conditions are identified [15]. Ecological plasticity and stability of spring wheat genotypes in terms of yield have been evaluated with different approaches $[8,11$, $13,15]$. It gives a comprehensive assessment of the varieties studied, but at the same time complicate analysis of the information obtained. Therefore, the relationship of adaptability parameters with each other and with yield was evaluated. The conditions in specific years of research are important: for certain varieties the variation range of regression coefficient for different three-year cycles of study is up to 2-3. Effective method of grouping samples by yield characteristics due to changes in growing conditions has been proposed which can be used as a supplement or alternative to other methods in the classification of bread wheat samples according to the level of ecological stability [11].

Thus, the aim of the study was to determine the level of ecological stability and plasticity of spring bread wheat varieties of different ecological and geographical origin in the ecological zones of the Forest-Steppe and Polissia of Ukraine.

\section{Materials and Methods}

The research was conducted during 2016-2018 in two agro-ecological zones: the Forest-Steppe (the V. M. Remeslo Myronivka Institute of Wheat of NAAS of Ukraine (MIW) and the Polissia (Nosivka Plant Breeding and Experimental Station of MIW (NPBES)). There were studied 14 varieties of spring bread wheat of different ecological and geographical origin: Elehiia myronivs'ka, Struna myronivs'ka, Kharkivs'ka 26, MIP Zlata, Panianka, Simkoda myronivs'ka, Etiud, Siuita, Heroinia (UKR), Koksa, Yasna (POL), Granny (AUT), Leguan (CZE), Venus (SYR).

Sowing was carried out in the optimal time on the experimental fields of breeding crop rotation with seed drill SKS-6-10 in four replications. The estimated area of the plot was $1 \mathrm{~m}^{2}$. Standard variety was Elehiia myronivs'ka.

To characterize the hydrothermal conditions, the hydrothermal coefficient of Selyaninov (HTC) [16] was calculated:

$$
\mathrm{HTC}=\mathrm{R} * 10 / \sum \mathrm{t},
$$

where $\mathrm{R}$ is the sum of precipitation (in $\mathrm{mm}$ ) for the period with an average daily air temperature above $10^{\circ} \mathrm{C}$;

$\sum \mathrm{t}$ is the sum of active temperatures for the same period.

According to the HTC values, the comfort of growing season conditions for the growth and development of winter wheat plants was determined: $0.4-0.7$ as very arid; $0.8-1.0$ as arid; $1.1-1.3$ as slightly arid; $1.4-1.6$ as optimal; $>1.6$ as waterlogged [16]. The parameters of stability and plasticity were determined by the method of Eberhart and Russell [2].

The regression coefficient $\left(b_{i}\right)$ characterizes the average response of the variety to changes in environmental conditions, indicates its plasticity and predicts the change of the trait studied within the conditions in which the study is conducted.

The regression coefficient was calculated by the formula [2]:

$$
\mathrm{b}_{\mathrm{i}}=\sum_{\mathrm{j}} \mathrm{Y}_{\mathrm{ij}} \times \mathrm{Ij} / \sum_{\mathrm{j}} \mathrm{I}_{\mathrm{j}}{ }_{\mathrm{j}}
$$


where $\Sigma_{\mathrm{j}} \mathrm{Y}_{\mathrm{ij}}$ is the sum yield of the $\mathrm{i}$-th variety in the $\mathrm{j}$-th year,

$\mathrm{Ij}$ is the value of environmental index;

$\Sigma_{\mathrm{j}} \mathrm{I}_{\mathrm{j}}{ }_{\mathrm{j}}$ is the sum of squares of the environmental index.

It is a positive value, but may be a negative one, e.g. for reduced yields when lodging or disease damage.

Variation in actual yield relative to regression line is determined by the standard deviation from the regression line $\left(\mathrm{S}^{2} \mathrm{~d}_{\mathrm{i}}\right)[2]$ :

$$
S^{2} d_{i}=[1 /(j-2)] \times\left[\sum_{j}\left(Y_{i j}-Y_{i}\right)^{2}-b_{i}^{2} \sum_{j}\left(Y_{. j}-Y_{. .}\right)^{2}\right]
$$

The trait (yield) stability variance $\left(\mathrm{S}^{2} \mathrm{~d}_{\mathrm{i}}\right)$ indicates how reliably the variety corresponds to the plasticity by the regression coefficient $b_{i}$. It is established that the increase in variety yield stability is accompanied by a decrease in its plasticity $\left(\mathrm{S}^{2} \mathrm{~d}_{\mathrm{i}}\right)$.

Statistical data processing was performed by methods of descriptive statistics and analysis of variance (ANOVA) [12] using Statistica 8.0 and Excel 2010.

\section{Results and Discussion}

\subsection{Hydrothermal Conditions of the Forest-Steppe and Polissia Zone}

During the research period (2016), the weather conditions in the Forest-Steppe and Polissia zones of Ukraine differed from the average long-term indicators in terms of temperature, precipitation and their distribution in individual months (Tables 1,2). It is known that the precipitation of the spring-summer period determines the level of yield of spring wheat depending on rainfall patterns. The average daily temperature for the period of sowing- seedling emergence in the zones of Forest-Steppe and Polissia of Ukraine was $+6.4^{\circ} \mathrm{C}$ and $+5.9^{\circ} \mathrm{C}$, whereas the average long-term indicators were at the level of $+9.4^{\circ} \mathrm{C}$ and $+9.1^{\circ} \mathrm{C}$. Precipitation in 2016 $(33.27 \mathrm{~mm})$ contributed to even emergence in the ForestSteppe zone of Ukraine. In the Polissia zone there was twice less precipitation $(15.76 \mathrm{~mm})$ which did not contribute to even emergence. In the period from seedling emergence to booting, the average daily temperature was $+13.0^{\circ} \mathrm{C}$ and $+11.7^{\circ} \mathrm{C}$ which is higher than the average long-term temperature by $0.2^{\circ} \mathrm{C}$ and $1.5^{\circ} \mathrm{C}$, respectively. Amount of precipitation during this period was $91.7 \mathrm{~mm}$, exceeding the average long-term amount for the Forest-Steppe zone (24.0 $\mathrm{mm})$. During the period from booting to heading, the air temperature in this year was at $+15.9^{\circ} \mathrm{C}$ which did not exceed the average long-term data, and for the Polissia zone it was $+16.4^{\circ} \mathrm{C}$ which is higher by $+0.5^{\circ} \mathrm{C}$ than the average longterm data. During the period of heading-full maturity, the air temperature in the Polissia zone was higher by $+2.6^{\circ} \mathrm{C}$ as compared to the average long-term data in the Forest-Steppe zone. Precipitation during this period in the Forest-Steppe zone was less than the long-term average by $19.4 \mathrm{~mm}$ which resulting in lower the moisture supply of plants and did not contribute to the formation of high yields.

Table 1. Hydrothermal conditions during spring bread wheat vegetation in the Forest-Steppe zone (2016-2018).

\begin{tabular}{|c|c|c|c|c|c|}
\hline Period & Parameters & 2016 & 2017 & 2018 & Average long-term value \\
\hline \multirow{7}{*}{ Sowing-emergence } & Sowing date & 18 March & 26 March & 14 April & - \\
\hline & Emergence date & 08 April & 07 April & 27 April & - \\
\hline & Duration, days & 22 & 13 & 14 & - \\
\hline & Sum precipitation, $\mathrm{mm}$ & 33.27 & 14.49 & 21.09 & 34 \\
\hline & Sum air temperature, ${ }^{\circ} \mathrm{C}$ & 139.8 & 133.2 & 206.5 & 130.9 \\
\hline & Average air temperature, ${ }^{\circ} \mathrm{C}$ & 6.4 & 10.3 & 14.75 & 9.4 \\
\hline & HTC & 0.9 & 0.8 & 1 & 2.6 \\
\hline \multirow{6}{*}{ Emergence-booting } & Booting date & 17 May & 19 May & 30 May & - \\
\hline & Duration, days & 40 & 42 & 33 & - \\
\hline & Sum precipitation, mm & 91.69 & 41.67 & 54.38 & 24 \\
\hline & Sum air temperature, ${ }^{\circ} \mathrm{C}$ & 520.2 & 475.1 & 611.9 & 357.3 \\
\hline & Average air temperature, ${ }^{\circ} \mathrm{C}$ & 13 & 11.3 & 18.5 & 13.2 \\
\hline & HTC & 1.1 & 0.9 & 0.9 & 0.67 \\
\hline \multirow{6}{*}{ Booting-heading } & Booting date & 17 May & 19 May & 30 May & - \\
\hline & Duration, days & 14 & 15 & 13 & - \\
\hline & Sum precipitation, mm & 54.11 & 14.74 & 25.61 & 44 \\
\hline & Sum air temperature, ${ }^{\circ} \mathrm{C}$ & 221 & 270.2 & 254.4 & 234.5 \\
\hline & Average air temperature, ${ }^{\circ} \mathrm{C}$ & 15.9 & 18 & 19.6 & 16.7 \\
\hline & HTC & 2.2 & 0.5 & 1 & 1.9 \\
\hline \multirow{7}{*}{ Heading-full maturity } & Heading date & 30. May. & 03 June & 12 June & - \\
\hline & Full maturity date & 10 July. & 18 July. & 25 July & - \\
\hline & Duration, days & 41 & 45 & 43 & - \\
\hline & Sum precipitation, mm & 70.6 & 65.4 & 132.6 & 90 \\
\hline & Sum air temperature, ${ }^{\circ} \mathrm{C}$ & 826.3 & 921.4 & 881.2 & 828 \\
\hline & Average air temperature, ${ }^{\circ} \mathrm{C}$ & 20.2 & 20.5 & 20.5 & 18.4 \\
\hline & HTC & 0.8 & 0.7 & 1.5 & 1,1 \\
\hline \multicolumn{2}{|c|}{ Sum air temperature $\left({ }^{\circ} \mathrm{C}\right)$ during active vegetation } & 1771.6 & 1666.7 & 1747.5 & 1550.7 \\
\hline \multicolumn{2}{|c|}{ Duration of active vegetation, days } & 95 & 102 & 89 & - \\
\hline \multicolumn{2}{|c|}{ Growing season, days } & 117 & 115 & 103 & - \\
\hline \multicolumn{2}{|l|}{ HTC } & 1.3 & 0.7 & 1.1 & 1.5 \\
\hline
\end{tabular}


In 2017, growing season for the Forest-Steppe was accompanied by increase in temperature and decrease in precipitation. The average daily temperature for the period of sowing-seedling emergence was $+10.3^{\circ} \mathrm{C}$ which was higher than average long-term value $+9.4^{\circ} \mathrm{C}$. Precipitation $(14.5 \mathrm{~mm})$ contributed to the emergence of seedlings. In the period from seedling emergence to booting, the average daily temperature was $+11.3^{\circ} \mathrm{C}$ which was lower than the average long-term value by $1.9^{\circ} \mathrm{C}$, and for the Polissia zone the average daily temperature was $+9.6^{\circ} \mathrm{C}$ which was lower by $3.6^{\circ} \mathrm{C}$ than the average long-term data. Precipitation during this period in the Forest-Steppe zone was $41.67 \mathrm{~mm}$, while the average longterm amount was $24.0 \mathrm{~mm}$. During the period from booting to heading, the air temperature was at $+18.0^{\circ} \mathrm{C}$ which exceeded the average long-term data by $1.3^{\circ} \mathrm{C}$. In the period of headingfull maturity, the air temperature was higher than the average long-term data. Precipitation during this period was less than the average long-term indicators by $24.6 \mathrm{~mm}$, resulting in lower rainfed environments for plants and did not contribute to the formation of high yields in the Forest-Steppe zone. The period of heading-full maturity in the Polissia zone was characterized by insufficient rainfall.

In 2018, the weather conditions of the spring period in the Forest-Steppe zone of Ukraine were characterized by late spring with a subsequent sudden increase in heat, accompanied by dry winds. The high average daily air temperature from sowing to seedling emergence at $+14.75^{\circ} \mathrm{C}$ and from seedling emergence to booting at $+18.5^{\circ} \mathrm{C}$, as well as precipitation $21.09 \mathrm{~mm}$ and $54.38 \mathrm{~mm}$ during these periods led to late and uneven emergence. During the period from booting to heading, the air temperature was at $+19.6^{\circ} \mathrm{C}$ which exceeded the average long-term data by $2.9^{\circ} \mathrm{C}$, and in the Polissia zone it was $+18.4^{\circ} \mathrm{C}$ which exceeded average long-term data by $2.5^{\circ} \mathrm{C}$. In the period of heading- full maturity, the air temperature in the Polissia zone was higher by $0.9^{\circ} \mathrm{C}$ as compared to the average long-term data. Precipitation during this period in the Forest-Steppe and Polissia zones exceeded the long-term average by $42.6 \mathrm{~mm}$ and $106.43 \mathrm{~mm}$ which improved the moisture supply of plants and contributed to yield formation.

Table 2. Hydrothermal conditions during spring bread wheat vegetation in the Polissia zone (2016-2018).

\begin{tabular}{|c|c|c|c|c|c|}
\hline Period & Parameters & 2016 & 2017 & 2018 & Average long-term value \\
\hline \multirow{6}{*}{ Sowing-emergence } & Sowing date & $20 \mathrm{March}$ & 27 March & 15 April & - \\
\hline & Emergence date & 09 April & 05 April & 30 April & - \\
\hline & Duration, days & 21 & 10 & 16 & - \\
\hline & Sum precipitation, $\mathrm{mm}$ & 15.76 & 5.33 & 1.78 & 39 \\
\hline & Sum air temperature, ${ }^{\circ} \mathrm{C}$ & 124.8 & 81.6 & 215.7 & 136.9 \\
\hline & Average air temperature, ${ }^{\circ} \mathrm{C}$ & 5.9 & 8.2 & 13.5 & 9.4 \\
\hline \multirow{7}{*}{ Emergence-booting } & Emergence date & 09 April & 05 April & 30 April & - \\
\hline & Booting date & 19 May & 20 May & 31 May & - \\
\hline & Duration, days & 41 & 45 & 31 & - \\
\hline & Sum precipitation, $\mathrm{mm}$ & 98.04 & 35.6 & 22.31 & 27 \\
\hline & Sum air temperature, ${ }^{\circ} \mathrm{C}$ & 477.9 & 430.7 & 530.6 & 369.5 \\
\hline & Average air temperature, ${ }^{\circ} \mathrm{C}$ & 11.7 & 9.6 & 17.1 & 13.2 \\
\hline & HTC & 1.3 & 0.8 & 0.4 & 0.67 \\
\hline \multirow{7}{*}{ Booting-heading } & Booting date & 19 May & 20 May & 31 May & - \\
\hline & Heading date & 01 June & 06 June & 14 June & - \\
\hline & Duration, days & 14 & 17 & 14 & - \\
\hline & Sum precipitation, $\mathrm{mm}$ & 112.27 & 18.8 & 13.22 & 39 \\
\hline & Sum air temperature, ${ }^{\circ} \mathrm{C}$ & 229.4 & 285.6 & 258 & 224.6 \\
\hline & Average air temperature, ${ }^{\circ} \mathrm{C}$ & 16.4 & 16.8 & 18.4 & 15.9 \\
\hline & HTC & 3.8 & 0.7 & 0.5 & 1.7 \\
\hline \multirow{7}{*}{ Heading-full maturity } & Heading date & 01 June & 06 June & 14 June & - \\
\hline & Full maturity date & 12 July & 20 July & 22 July & - \\
\hline & Duration, days & 42 & 44 & 38 & - \\
\hline & Sum precipitation, mm & 68.16 & 56.64 & 203.43 & 97 \\
\hline & Sum air temperature, ${ }^{\circ} \mathrm{C}$ & 874.1 & 1103.4 & 746.5 & 8.34 \\
\hline & Average air temperature, ${ }^{\circ} \mathrm{C}$ & 21.0 & 25.1 & 19.6 & 18.7 \\
\hline & HTC & 0.7 & 0.5 & 2.7 & 1.2 \\
\hline \multicolumn{2}{|c|}{ Growing season, days } & 117 & 115 & 103 & - \\
\hline \multicolumn{2}{|l|}{ HTC } & 1.3 & 0.7 & 1.1 & 1.5 \\
\hline
\end{tabular}

For the Forest-Steppe and Polissia zones of Ukraine, the hydrothermal coefficient in 2016 (HTC $=1.3,1.5$, respectively) and 2018 (HTC $=1.1,1.0$, respectively) was characterized by optimal rainfed conditions, and in 2017 
drought conditions were observed (HTC $=0.7$ in both zones) which did not contribute to grain formation and filling in these ecological zones of spring bread wheat growing.

\subsection{Evaluation of Spring Wheat Varieties by Yield}

Productivity or yielding capacity is the main feature that characterizes the economic value of the varieties created. The productivity of spring wheat and the expression of its individual components are significantly affected by environmental conditions. In years with different moisture supply and temperature regime, the variety is one of the reserves for increasing the yield and resistance of spring bread wheat to adverse environmental factors It was found that precipitation at the vegetative growth stage was a positive factor and the most favorable in determining grain yield, while the influence of minimum temperatures reduced grain yield. The results of the research show that varieties of different ecological and geographical origin varied in terms of yield in different ecological zones of cultivation.

The average yield level in the conditions of the MIW (Forest-Steppe) was $3.55 \mathrm{t} /$ ha and varied from $2.93 \mathrm{t} / \mathrm{ha}$ (min) to $4.01 \mathrm{t} / \mathrm{ha}(\max )$. For the Forest-Steppe zone, there were identified the spring bread wheat varieties MIP Zlata, Struna myronivs'ka, Kharkivs'ka 26, Simkoda myronivs'ka, Panianka (UKR), Koksa, Yasna (POL), and Leguan (CZE) which exceeded the yield level of the standard variety Elehiia myronivs'ka (3.40 t/ha). The higher level of yield was formed at the NPBES (Polissia) where growing seasons were characterized by optimal moisture in the period 2016-2018 with variation of the average yield from $3.78 \mathrm{t} / \mathrm{ha}$ in 2018 $(\min )$ to $6.06 \mathrm{t} / \mathrm{ha}(\max )$ in 2017 . For this ecological zone there were identified the varieties Koksa (POL), Simkoda myronivs'ka, Leguan (CZE), Struna myronivs'ka, MIP Zlata (UKR) that were at the level and exceeded the yield of standard variety Elehiia myronivska (5.11 t/ha).

Over the years of the research, the spring bread wheat varieties Simkoda myronivska, Struna myronivska, MIP Zlata (UKR), Koksa (POL), and Leguan (CZE) have been identified by increased yield in the Forest-Steppe and Polissia of Ukraine, so they are recommended for growing in both ecological zones.

\subsubsection{Factors Influencing on the Yield of Spring Wheat}

Based on the analysis of variance, the parts of sum square for the factors studied in yield formation of spring bread wheat were determined (Figure 1). The most influence on yield variation was determined for the conditions of the agroecological zone $(29.2 \%)$; the weather conditions in the year of growing caused $16.3 \%$ of yield variation, $8.0 \%$ resulted from the influence of genotype, $27.1 \%$ due to the interaction of factors "year $\times$ zone". A significant part of sum square resulted from residuals $7.3 \%$. This may be explained by differences in weather conditions during the years of the research, as well as the influence of other unaccounted natural and agronomic factors. However, it should be noted a high level of interaction "variety $\times$ year $\times$ zone" $-7.8 \%$. Among the factors the impact of agro-ecological growing zone was the most, and among the interactions the interaction "year $\times$ zone" was the most significant.

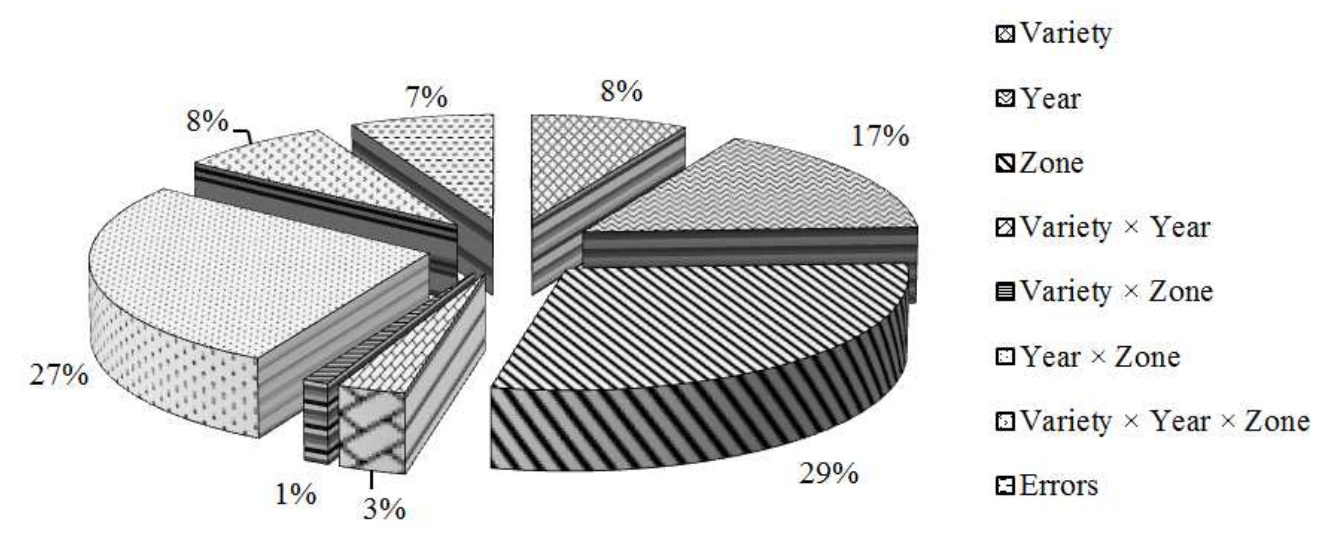

Figure 1. The part of sum square in yield variation of spring bread wheat (2016-2018).

Analysis of the yield of spring bread wheat varieties showed that its variability was largely due to environmental factors, the interaction between the place of growing (zone) and environmental factors (years), then random and uncertain factors (unaccounted factors, objective and subjective errors) in agronomic patterns during the experiment) and to a lesser extent due to genetic differences in yield between varieties. However, it should be noted that the varieties tested in this experiment were quite close in their productivity potential and often genetically differed by no more than 5-20\%. However, with a high level of genetic potential of productivity, differences within even $1.0 \%$ are significant and can have a notable economic effect in farming.

\subsubsection{Ecological Plasticity and Stability of Spring Wheat Varieties}

Calculations of ecological plasticity of the genotypes studied in the Forest-Steppe zone showed that the varieties MIP Zlata (UKR) $\left(b_{i}=1.46\right)$, Struna myronivs'ka (UKR) $\left(b_{i}\right.$ = 1.19), Panianka (UKR) $\left(b_{i}=1.35\right)$, Kharkivs'ka $26(\mathrm{UKR})$ $\left(b_{i}=1.15\right)$, Simkoda myronivs'ka (UKR) $\left(b_{i}=1.34\right)$ were characterized with high plasticity in terms of yield, because the regression coefficient was more than 1.0. They can be grown on intensive background, as they respond well to 
changing growing conditions. The varieties Elehiia myronivs'ka (UKR) $\left(b_{i}=1.01\right)$, Koksa (POL) $\left(b_{i}=0.92\right)$, Leguan $(C Z E)\left(b_{i}=0.87\right)$, Granny (AUT) $\left(b_{i}=0.98\right)$, Venera $(\mathrm{SYR})\left(\mathrm{b}_{\mathrm{i}}=1.03\right)$, Heroinia $(\mathrm{UKR})\left(\mathrm{b}_{\mathrm{i}}=1.02\right)$ were moderately plastic, because their plasticity index was close to 1.0. Other genotypes studied in terms of yield are low-plastic $\left(b_{i}<1\right)$. These varieties did not significantly reduce yields under limited growing conditions due to their high resistance to adverse environmental factors (Table 3 ).
Calculations of ecological stability $\left(\mathrm{S}^{2} \mathrm{~d}_{\mathrm{i}}\right)$ of wheat varieties showed that the best stability parameters were identified for the varieties Elehiia myronivs'ka (UKR) $\left(\mathrm{S}^{2} \mathrm{~d}_{\mathrm{i}}\right.$ $=0.01)$, MIP Zlata (UKR) $\left(\mathrm{S}^{2} \mathrm{~d}_{\mathrm{i}}=0.00\right)$, Koksa $(\mathrm{POL})\left(\mathrm{S}^{2} \mathrm{~d}_{\mathrm{i}}=\right.$ 0.03), Leguan (CZE) $\left(\mathrm{S}^{2} \mathrm{~d}_{\mathrm{i}}=0.01\right)$, Simkoda myronivs'ka (UKR) ( $\left.\mathrm{S}^{2} \mathrm{~d}_{\mathrm{i}}=0.06\right)$, Panianka (UKR) $\left(\mathrm{S}^{2} \mathrm{~d}_{\mathrm{i}}=0.03\right)$, Kharkivs'ka $26(\mathrm{UKR})\left(\mathrm{S}^{2} \mathrm{~d}_{\mathrm{i}}=0.00\right)$, Granny $(\mathrm{AUT})\left(\mathrm{S}^{2} \mathrm{~d}_{\mathrm{i}}=\right.$ $0.02)$ and Heroinia (UKR) $\left(\mathrm{S}^{2} \mathrm{~d}_{\mathrm{i}}=0.01\right)$.

Table 3. Ecological plasticity and yield stability of spring bread wheat varieties in the Forest-Steppe zone (2016-2018).

\begin{tabular}{|c|c|c|c|c|c|c|}
\hline \multirow{2}{*}{ Variety } & \multirow{2}{*}{ Country of Origin } & \multicolumn{3}{|c|}{ Yield, t/ha } & \multicolumn{2}{|c|}{ Parameters } \\
\hline & & 2016 & 2017 & 2018 & $\mathbf{b}_{\mathbf{i}}$ & $S^{2} d_{i}$ \\
\hline Elehiia myronivs'ka (standard) & UKR & 4.60 & 2.74 & 3.11 & 1.01 & 0.01 \\
\hline MIP Zlata & UKR & 5.45 & 2.95 & 3.61 & 1.46 & 0.00 \\
\hline Struna myronivs'ka & UKR & 4.89 & 2.59 & 4.22 & 1.19 & 0.57 \\
\hline Koksa & POL & 4.64 & 2.99 & 3.69 & 0.92 & 0.03 \\
\hline Leguan & $\mathrm{CZE}$ & 4.60 & 3.06 & 3.64 & 0.87 & 0.01 \\
\hline Simkoda myronivs'ka & UKR & 5.01 & 2.61 & 3.64 & 1.34 & 0.06 \\
\hline Yasna & POL & 4.01 & 2.59 & 4.53 & 0.60 & 0.46 \\
\hline Panianka & UKR & 5.00 & 2.62 & 3.53 & 1.35 & 0.03 \\
\hline Kharkivs'ka 26 & UKR & 4.74 & 2.74 & 3.39 & 1.15 & 0.00 \\
\hline Granny & AUT & 4.31 & 2.66 & 2.99 & 0.98 & 0.02 \\
\hline Heroinia & UKR & 4.20 & 2.47 & 2.86 & 1.02 & 0.01 \\
\hline Venera & SYR & 4.34 & 2.86 & 2.11 & 1.03 & 0.89 \\
\hline Siuita & UKR & 3.86 & 3.16 & 2.14 & 0.59 & 0.95 \\
\hline Etiud & UKR & 3.49 & 2.79 & 2.53 & 0.48 & 0.14 \\
\hline Mean & - & 4.53 & 2.91 & 3.31 & - & - \\
\hline $\min$ & - & 3.49 & 2.47 & 2.11 & - & - \\
\hline $\max$ & - & 5.01 & 3.16 & 4.53 & - & - \\
\hline
\end{tabular}

min is minimum value, max is maximum value.

The values of ecological plasticity and stability of most varieties of spring bread wheat in terms of yield plasticity in the Polissia including the standard variety were within 1.1 or very close to 1.0 and differed little from the average group ecological plasticity. The varieties Elehiia myronivs'ka (UKR) $\left(b_{i}=1.35\right)$, MIP Zlata $(U K R)\left(b_{i}=1.43\right)$, Struna myronivs'ka (UKR) $\left(b_{i}=1.52\right)$, Koksa (POL) $\left(b_{i}=1.81\right)$, Leguan $(\mathrm{CZE})\left(\mathrm{b}_{\mathrm{i}}=1.30\right)$, Simkoda myronivs'ka (UKR) $\left(\mathrm{b}_{\mathrm{i}}=\right.$ 1.33) were highly plastic and they can be attributed to varieties of intensive type with a positive response to changing environmental conditions (Table 4).

Table 4. Ecological plasticity and yield stability of spring bread wheat varieties in the Polissia zone (2016-2018).

\begin{tabular}{|c|c|c|c|c|c|c|}
\hline \multirow{2}{*}{ Variety } & \multirow{2}{*}{$\begin{array}{l}\text { Country of } \\
\text { Origin }\end{array}$} & \multicolumn{3}{|c|}{ Yield, t/ha } & \multicolumn{2}{|c|}{ Parameters } \\
\hline & & 2016 & 2017 & 2018 & $\mathbf{b}_{\mathbf{i}}$ & $\mathbf{S}^{2} \mathbf{d}_{\mathrm{i}}$ \\
\hline Elehiia myronivs'ka (standard) & UKR & 5.25 & 6.40 & 3.70 & 1.35 & 0.01 \\
\hline MIP Zlata & UKR & 5.21 & 6.75 & 3.87 & 1.43 & 0.03 \\
\hline Struna myronivs'ka & UKR & 5.39 & 6.67 & 3.63 & 1.52 & 0.01 \\
\hline Koksa & POL & 5.10 & 6.83 & 3.20 & 1.81 & 0.00 \\
\hline Leguan & $\mathrm{CZE}$ & 4.78 & 6.45 & 3.82 & 1.30 & 0.13 \\
\hline Simkoda myronivs'ka & UKR & 4.66 & 6.54 & 3.85 & 1.33 & 0.26 \\
\hline Panianka & UKR & 4.51 & 6.25 & 3.86 & 0.36 & 0.05 \\
\hline Kharkivs'ka 26 & UKR & 5.18 & 5.27 & 3.83 & 0.73 & 0.23 \\
\hline Granny & AUT & 4.68 & 5.58 & 4.04 & 0.76 & 0.02 \\
\hline Heroinia & UKR & 4.60 & 5.62 & 3.93 & 0.84 & 0.00 \\
\hline Venera & SYR & 4.25 & 6.27 & 3.56 & 0.55 & 0.04 \\
\hline Siuita & UKR & 4.58 & 5.27 & 3.91 & 0.68 & 0.00 \\
\hline Etiud & UKR & 4.07 & 5.18 & 3.69 & 0.32 & 0.00 \\
\hline $\min$ & - & 4.25 & 5.18 & 3.20 & - & - \\
\hline $\max$ & - & 5.39 & 6.83 & 4.04 & - & - \\
\hline
\end{tabular}

min is minimum value, max is maximum value.

The less square deviation of the actual yields from the theoretically expected $\left(\mathrm{S}^{2} \mathrm{~d}_{\mathrm{i}}\right)$, the more stable the variety is.
Among the varieties studied, there were the most stable ones Elehiia myronivs'ka (UKR) $\left(\mathrm{S}^{2} \mathrm{~d}_{\mathrm{i}}=0.01\right)$, Simkoda 
myronivs'ka (UKR) $\left(\mathrm{S}^{2} \mathrm{~d}_{\mathrm{i}}=0.26\right)$, MIP Zlata (UKR) $\left(\mathrm{S}^{2} \mathrm{~d}_{\mathrm{i}}=\right.$ $0.03)$, Struna myronivs'ka (UKR) $\left(\mathrm{S}^{2} \mathrm{~d}_{\mathrm{i}}=0.01\right)$, Koksa (POL) $\left(\mathrm{S}^{2} \mathrm{~d}_{\mathrm{i}}=0.00\right)$, Panianka (UKR) $\left(\mathrm{S}^{2} \mathrm{~d}_{\mathrm{i}}=0.05\right)$, Granny (AUT) $\left(S^{2} d_{i}=0.02\right)$, Heroinia (UKR) $\left(S^{2} d_{i}=0.00\right)$, Venera (SYR) $\left(\mathrm{S}^{2} \mathrm{~d}_{\mathrm{i}}=0.00\right)$, Siuita (UKR) $\left(\mathrm{S}^{2} \mathrm{~d}_{\mathrm{i}}=0.00\right)$, and Etiud (UKR) $\left(\mathrm{S}^{2} \mathrm{~d}_{\mathrm{i}}=0.00\right)$.

High plastic reaction to growing conditions by yield $\left(b_{i}>1\right)$ in the Forest-Steppe and Polissia zones was determined in the varieties: Koksa $(\mathrm{POL})\left(\mathrm{b}_{\mathrm{i}}=1.02\right)$, Simkoda myronivs'ka $(\mathrm{UKR})\left(b_{\mathrm{i}}=1.02\right)$, Granny (AUT) $\left(b_{\mathrm{i}}=1.03\right)$, Heroinia (UKR) $\left(b_{i}=1.01\right)$, Etiud (UKR) $\left(b_{i}=1.02\right)$. These varieties can be characterized by adaptive properties as intensive ones with a pronounced reaction to the environment, i.e. relatively high yields may be the result of a specific reaction to more favorable growing conditions.

Over the years of the research, an increase in the stability has been observed which affected the probable decrease in the yield of certain varieties. According to the stability variance $\left(S^{2} d_{i}\right)$, low-plastic forms with low value of $S^{2} d_{i}$ are considered widely adapted, but unprofitable genotypes and are classified as extensive, while high plastic forms with low value of $\mathrm{S}^{2} \mathrm{~d}_{\mathrm{i}}$ are classified as intensive genotypes. The calculation of ecological plasticity and stability level allowed differentiating the varieties of spring bread wheat according to the range of their response to variation of growing conditions and adaptive potential.

\section{Conclusions}

Thus, based on the analysis of contrasting hydrothermal conditions of 2016-2018 in agroecological research zones, assessment of adaptive capacity parameters and yield level of promising varieties of spring wheat, the peculiarities of plant growth and development were determined and variety variability depending on the outecological influence. This makes it possible to obtain reliable data on the realization of the yield potential of the studied varieties.

The results of the analysis of variance showed the significant influence of various factors (varieties, hydrothermal conditions, agro-ecological zones and their interaction) on the yield of spring bread wheat.

The parameters of ecological plasticity and stability are determined, which enabling to differentiate varieties of spring bread wheat according to the total variation range in changing growing conditions and to adaptive potential.

\section{References}

[1] Altukhov, YU. P. (1983). Genetic processes in populations. Moscow: Nauka. 279 p. (RU).

[2] Eberhart, S. A., \& Russell, W. A. (1966). Stability parameters for comparing varieties. Crop Sci., 6 (1), 36-40.

[3] Grogan, S. M., Anderson, J., Baenziger, P. S., Frels, K., Guttieri, M. J., Haley, S. D., Kim, K., Liu, S., McMaster, G. S., Newell, M., Prasad, P. V., Reid, S. D., Shroyer, K. J., Zhang, G., Akhunov, E., \& Byrne, P. (2016). Phenotypic plasticity of winter wheat heading date and grain yield across the US great plains. Crop Sci., 56 (5), 2223-2236. doi: 10.2135/cropsci2015.06.0357.

[4] Khangil'din, V. V., \& Litvinenko, N. A. (1981). Homeostaticity and adaptability of winter wheat varieties. Scientific and Technical Bulletin of VSGI, 39, 8-14 (RU).

[5] Herman, J. J., \& Sultan, S. E. (2011). Adaptive transgenerational plasticity in plants: Case studies, mechanisms, and implications for natural populations. Front Plant Sci., 2 (102), 1-10. doi: 10.3389/fpls.2011.00102.

[6] Holik, O. V., \& Kabatsiura, A. A. (2012). Characteristics of the source material of spring wheat and emmer by ecological plasticity of yield. Plant Breeding and Seed Production, 101, 139-149 (UA). doi: 10.30835/2413-7510.2012.59747.

[7] Ivanyuk, S. V., \& Barvinchenko, S. V. (2017). Vicia faba breeding in Ukraine. In Materials of the international scientific and practical conference "Strategy and priorities for the development of agriculture and selection of field crops in Belarus" (pp. 295-300). Zhodino (RU).

[8] Khomenko, S. O., Kochmarskyi, V. S., Fedorenko, I. V., \& Fedorenko, M. V. (2018). Stability and plasticity of collection samples of bread spring wheat by productivity indices. Bulletin of Uman National University of Horticulture, 1, 4347 (UA). doi: 10.31395/2310-0478-2018-1-43-47.

[9] Kravets, O. P., Sokolova, D. O., Berestyana, A. M., Shnurenko, O. R., Bannikova, M. O., Morgun, B. V., Kuchuk, M. V., \& Grodzinsky, D. M. (2016). Correlation between ecological plasticity of elite winter wheat varieties and DNA methylation pattern polymorphism within variety. Sci. Innov., 12 (2), 50-59. doi: 10.15407/scine12.02.050.

[10] Kryuchkov, A G., \& Sandakova, G. N. (2003). The main indicators of the assessment of the variety. Grain Farming, 6, 16-20 (RU).

[11] Leonov, O. Yu. (2013). Grouping of common wheat samples on plasticity and stability expression of quantitative traits. Plant Genetic Resources, 13, 28-39 (UA).

[12] Little, T. M., \& Hills, F. J. (1978). Agricultural Experimentation: Design and Analysis. New York: John Wiley \& Sons. 368 p.

[13] Melekhina, T. S., Pinchuk, L. G., \& Sekacheva, V. M. (2015). Ecological flexibility of the soft spring wheat varieties regarding crop capacity and grain quality in the varying conditions of South-East of Western Siberia (Kemerovo region). The Bulletin of KrasGAU, 4 (103), 126130 (RU).

[14] Potanin, V. G., Aleynikov, A. F., \& Stepochkin, P. I. (2014). A new approach to assessing the ecological plasticity of plant varieties. Vavilov Journal of Genetics and Breeding, 18 (3), 548-552 (RU).

[15] Pushkarev, D. V., Shamanin, V. P., Krasnova, Yu. S., Karakoz, I. I., Chursin, A. S., \& Kuz'min, O. G. (2017). Ecological plasticity and stability of spring wheat varieties in the steppe zone of the Omsk region. Bulletin of Omsk SAU, 4, 55-64 (RU).

[16] Selyaninov, G. T. (1937). Methods of agricultural characteristics of climate. In World Agroclimatic Reference Book. (pp. 4-29). Leningrad, Moscow: Gidrometeoizdat (RU). 
[17] Shchypak, H. V., Svyatchenko, S. I., \& Nepochatov, M. I. (2014). Evaluation of winter triticale variety samples by ecological plasticity and stability of basic productivity traits. Bulletin of the Center for Science Provision of Agribusiness in the Kharkiv region, 16, 247-256 (UA).

[18] Solonechnyi, P. M. (2013). Homeostaticity and selection value of modern varieties of spring barley. Plant Breeding and Seed Production, 103, 36-41 (UA). doi: 10.30835/24137510.2013.54064.
[19] Tétard-Jones, C., \& Leifert, C. (2011). Plasticity of yield components of winter wheat in response to cereal aphids. NJAS: Wageningen Journal of Life Sciences, 58 (3-4), 139143. doi: 10.1016/j.njas.2011.01.003.

[20] Zhuchenko, A. A. (2011). Agricultural systems and their development. Biologization, greening, energy conservation, economics. In Farming Systems of the Stavropol region (pp. 19-20). Stavropol (RU). 